\title{
Ecological Civilisation and the Political Limits of a Chinese Concept of Sustainability
}

\section{Coraline Goron}

\section{(2) OpenEdition}

\section{Journals}

Electronic version

URL: http://journals.openedition.org/chinaperspectives/8463

DOI: 10.4000/chinaperspectives.8463

ISSN: 1996-4617

\section{Publisher}

Centre d'étude français sur la Chine contemporaine

Printed version

Date of publication: 31 December 2018

Number of pages: $39-52$

ISSN: 2070-3449

\section{Electronic reference}

Coraline Goron, «Ecological Civilisation and the Political Limits of a Chinese Concept of Sustainability », China Perspectives [Online], 2018-4 | 2018, Online since 31 December 2018, connection on 22 March 2020. URL : http://journals.openedition.org/chinaperspectives/8463 ; DOI : https://doi.org/10.4000/ chinaperspectives.8463 


\title{
Ecological Civilisation and the
}

\section{Political Limits of a Chinese}

\section{Concept of Sustainability}

CORALINE GORON

\begin{abstract}
Since it was first endorsed by President Hu Jintao in 2007, ecological civilisation (EC) has developed into a central element of the green rhetoric of the Chinese Communist Party (CCP). The political promotion of EC by the Chinese leadership has been supported by a theoretical argument, according to which EC could provide an alternative development theory capable of revolutionising the ecocidal global economic order and bring about a global ecological transition. Does EC present a new theory of development enabling Chinese scholars to contribute meaningfully to the global discussion on sustainable development? What does the circulation of $\mathrm{EC}$ between the political and academic spheres tell us about the ability of "social sciences with Chinese characteristics" to produce innovative concepts and theories of sustainability? This article analyses what ecological civilisation brings to the study of sustainability in China as well as globally, through an analysis of the relationship between knowledge and power that has underpinned its development. Based on a qualitative analysis of political documents and a comprehensive review of Chinese academic publications on EC, it unpacks the different layers of political and theoretical meanings that have been invested in the concept of EC over time by CCP ideologues and by scholars; and then analyses the influence that EC has had on China's sustainability research. It argues that the political discourse of EC has increasingly limited the way in which scholars engage critically with capitalism, democracy, and other elements of green political theory. However, it also shows that many Chinese scholars, while subscribing to the EC discourse, have continued to press for the development of their disciplinary contribution to the global scientific discussion on sustainability.
\end{abstract}

KEYWORDS: ecological civilisation, political discourse, Chinese social science research on ecology.

\section{Introduction}

$\mathrm{N}$ early half a century after the publications of the Club of Rome's Limits to Growth in 1972, the global horizon of sustainability remains bleak: the depletion of resources and the loss of biodiversity has accelerated, and the Paris Agreement signed in 2015 has yet to produce the commitments, let alone the change required to prevent catastrophic climate change. The response offered by the Chinese leadership has been framed around the promotion of the concept of ecological civilisation (shengtai wenming 生态文明), which has come to replace mentions of the international concept of sustainable development (SD). This article examines what ecological civilisation (EC) brings to the study of sustainability in China as well as globally, through an analysis of the relationship between knowledge and power that has underpinned its development. This relationship has been marked by an unprecedented politicisation of environmental protection by the Chinese Communist Party (CCP) leadership and by increasing demands for the development of Chinese social sciences innovations to address the social and political problems facing China, including the ecological transition (Zheng 2011; Ping 2012).

Since it was put forward by $\mathrm{Hu}$ jintao in 2007, EC has progressively been elevated to the rank of a paramount objective of the CCP in 2012, and of a constitutional principle of the People's Republic in 2018. Internationally as well, the concept has received increasing attention, especially since the Trump administration pulled the United States out of global environmental governance (e.g., Yu et al. 2014; China Dialogue 2018). The political promotion of $\mathrm{EC}$ by the Chinese leadership has been supported by a theoretical argument, according to which $\mathrm{EC}$ could provide an alternative development theory capable of revolutionising the global economic order and bring about a global ecological transition (Pan 2016; Gare 2016; Foster 2017). However, the origins of EC suggest that it is science, instead, that has been called upon to support the political legitimacy-building agenda of the CCP. This argument is supported by evidence of the way in which highly respected Chinese academic publications such as Social Sciences in China have praised the CCP's "wisdom" for promoting EC (Ke et al. 2013).

However, one can also find many instances where Chinese scholars have used EC more as a catchword to present environmental policy advice of different kinds. For instance, the widely cited article on "Ecological Civilisation Construction" by the famous environmental lawyer Professor Wang Canfa provides a detailed analysis of the flaws and desirable reforms of China's legal system for environmental protection (Wang C. 2014). (1)

If ecological civilisation is not just a political catchword, has it given rise to an innovative theory of development enabling Chinese scholars to con-

According to the CNKI database's metrics, it has been downloaded 12,883 times and cited 123 times. 
7000

\begin{tabular}{|ll|}
6000 & $\begin{array}{l}\text { Ecological Civilisation } \\
\text { (academic papers) }\end{array}$ \\
& $\begin{array}{l}\text { Ecological Civilisation } \\
\text { (newspapers) }\end{array}$ \\
\hline
\end{tabular}

4000

3000

1000

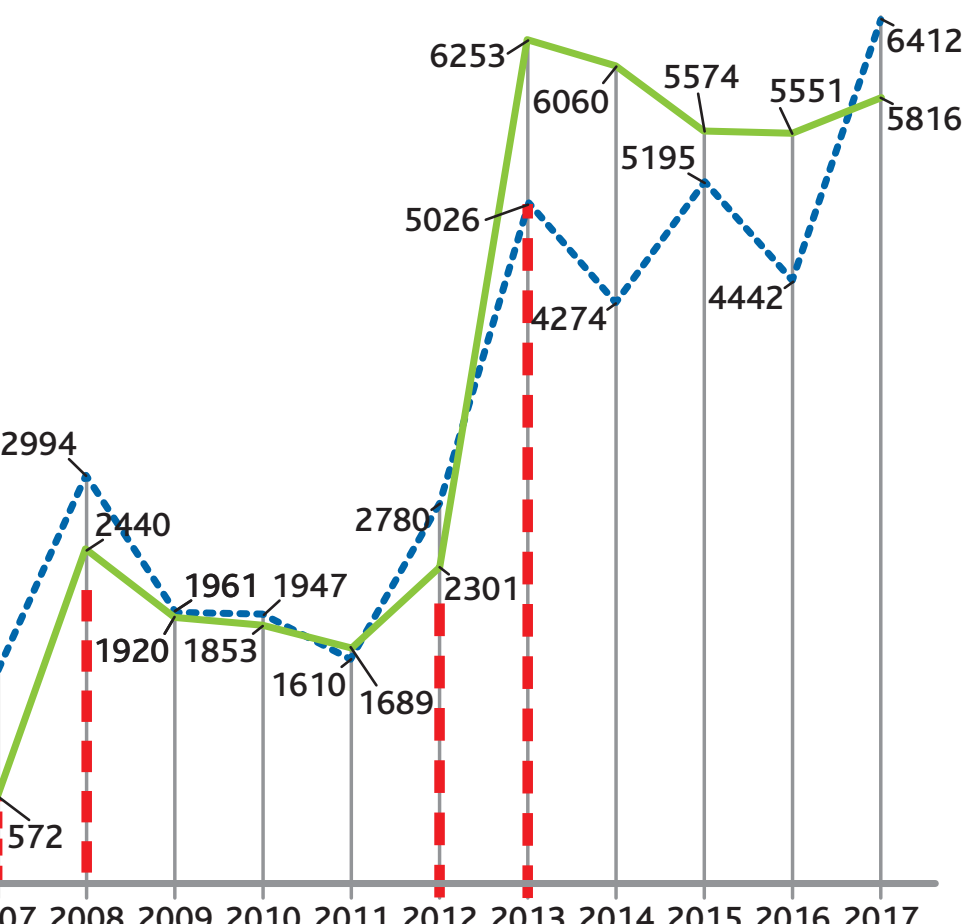

200020012002200320042005200620072008200920102011201220132014201520162017

Source: CNKI article search compiled by the author.

Note: The CNKI database of academic journals (qikan 期刊) and newspapers (baozhi 报纸) was searched with the topic ecological civilisation (shengtai wenming 生态文明) on 13 May 2018.

tribute meaningfully to the global discussion on sustainable development? What does the circulation of EC between the political and academic spheres tell us about the ability of "social sciences with Chinese characteristics" to produce innovative concepts and theories of sustainability?

The relationship between science and political power has always been a major source of interrogation and debate for China scholars. Since the reestablishment of social sciences in the late 1970s, Chinese academics have had to navigate between different influences, including censorship and the ideological claims continuously made by the CCP, the marketisation of knowledge production, and the normative influence of foreign concepts and methodologies (Frenkiel 2015; Zhang 2008).

The situation has fluctuated over time and across disciplines, as well as issue areas. The mainstream view is that environmental studies have gained more critical space than many other social and political issues (Frenkiel 2015), and some authors have even argued that environmental protection has provided a "relatively comfortable zone" for scholars to voice criticisms of policies and institutions, as well as to influence policy-making (Wu 2009). However, other scholars have pointed out the underdevelopment of important sub-disciplines such as environmental history or political ecology, as well as the significant political barriers that remain for conducting empirical research (Yeh 2015; Lora-Wainwright 2017; Lords 2018).

This article does not address the problems of conducting empirical research. It focuses on the relationship between knowledge and power in the formulation of a new Chinese concept of sustainability. It seeks to evaluate the degree of ideational freedom and influence that academics have enjoyed in discussing the concept of EC, their motivations for doing so, as well as their success in developing innovative conceptions of sustainability based on their knowledge of China. The handful of English-speaking papers that have analysed EC illustrate the confusion and scepticism spurred by the promotion of EC beyond its borders. Geall and Ely (2017) and Marinelli (2018) have argued that it offers a narrative that skilfully taps into China's institutional strengths to promote the ecological transition. Heurtebise and Gaffric, however, have argued that EC cultivates a cultural chauvinism in contradiction with the globalised nature of environmental threats and incompatible with the need for collaborative action (Gaffric and Heurtebise 2013; Heurtebise 2017). Yet, other scholars have on the contrary argued that $\mathrm{EC}$ merely repeats the globally dominant discourses of green capitalism and ecological modernisation, instead of providing an alternative to them (Hubbert 2015; Chen 2012; Lord 2018).

This article analyses the roots of these different arguments, first, by unpacking the different layers of political and theoretical meanings that have been invested in the concept of EC over time by CCP ideologues and by scholars; and secondly, by examining the influence that EC has had in turn on sustainability research in China. It argues that EC has increasingly tended to restrain both public and scholarly debate within discursive boundaries controlled by CCP propaganda, hindering capacities to engage critically with capitalism, democracy, and other foundations of green political thought. However, it also shows that many Chinese scholars, while paying lip service to the EC discourse, have remained committed to their academic research agenda and have continued to press for the development of their disciplinary contribution to the global scientific discussion on sustainability. 


\section{The making of a Chinese concept of sustainable development}

Ecological civilisation has been used first and foremost by the CCP. Although the term has been sporadically coined in some academic works since the 1980s, it is unquestionably its endorsement by Hu Jintao in 2007 and then by Xi Jinping in 2013 that triggered a boom in academic research. As shown in Graph 1, as with official newspapers, the number of academic articles on EC suddenly grew from 345 in 2006 to 2,422 in 2008, and then surged again to 6,222 articles in 2013.

It is therefore necessary to introduce the political genealogy of EC before introducing the intellectual contributions that have fleshed it out over time. Doing so also identifies the strengthening of political propaganda under $X i$ jinping.

\section{The political opportunity for ecological civilisation}

Ecological civilisation appeared in official policy documents for the first time in a 2003 central policy document on reforestation (Huan 2014). (2) However, it was only when President Hu Jintao mentioned it in his 2007 work report to the $17^{\text {th }}$ Communist Party Congress that the term began to emerge politically. ${ }^{(3)}$ Still, the report did not define EC, and the signature event of that Congress was more the consecration of Hu Jintao's feature concept of "scientific development" in the CCP constitution. EC's political momentum didn't really build until five years later in 2012, when Hu Jintao's second work report to the 18th Party Congress dedicated a whole section to the "construction of an ecological civilisation," while an amendment to the CCP constitution listed it as one of the five core missions of the CCP (together with political, cultural, economic, and social construction).

$X i$ jinping then upheld EC as the key concept used to "green" the institutions of the Party-state. Some of the milestones in this process include the creation in 2013 of the first CCP organ dedicated to ecology, the "Task Force for the Promotion of Economic Development and Ecological Civilisation" (4)i the Politburo's adoption of a landmark "Central Opinion Document on Ecological Civilisation Construction" in March 2015, followed by an "Ecological Civilisation Construction Action Plan" six months later that recentralised power and aligned the environmental responsibility of local party and state officials (Geall and Ely 2017; Geall 2015); (5) and the rolling out of a national campaign of Central Environmental Inspections (Zhongyang huanbao duchazu 中央环保督察祖) that reportedly punished more than 29,000 companies, imposed 1.43 billion RMB of fines (US\$216 million $\left.{ }^{(6)}\right)$, detained 1,527 individuals, and disciplined 18,199 officials across the country by $2018^{(7)}$. Once ecological civilisation was singled out as a constitutive element of $X_{i}$ Jinping's "Socialism with Chinese Characteristics for a New Era" (Xi Jinping xin shidai Zhongguo tese shehuizhuyi sixiang 习近平新时代中国特色社会主 义思想) , ${ }^{(8)}$ it was also ratified in the Constitution of the PRC in 2018, ${ }^{\left({ }^{(9)}\right.}$ and an unforeseen administrative reshuffling was carried out, creating a large Ministry of Ecology and Environment (shengtai huanjing bu 生态环境部) in March 2018

Why did the CCP choose the term "ecological civilisation" instead of sustainable development? The term "civilisation" has a specific political meaning in the rhetoric of the CCP since Deng Xiaoping's campaign in the 1980s to promote a "spiritual civilisation" (jingshen wenming 精神文明) complementing the "material civilisation" (wuzhi wenming 物质文明) brought about by economic reforms (Barmé 2013). Deng wanted to signal that modernisation was not just about getting rich; he also wanted the CCP to respond to societal demands for political reforms while countering and delegitimising democratic alternatives denounced as "spiritual pollution" (Wang 2018).

It is significant that the first academic mentions of "ecological civilisation" also appeared in that political context (Yu 2010; Huan 2016a; Marinelli 2018). In 1985, Guangming ribao 光明日报 published a Russian article in which the term "ecological culture" was translated as "ecological civilisation." Two years later, at a 1987 National Conference on agriculture, the agro-economist Ye Qianji also used the term to plead for a more sustainable agricultural development model (Huan 2016a; Pan 2016; Marinelli 2018). (10) However, contrary to claims sometimes made by the Chinese government that EC dates from these years, it is clear that, at that time, EC was not picked up by the leadership and that debates on "civilisation" overlooked environmental issues. Instead, it is the concept of sustainable development (SD), translated as kechixu fazhan 可持续发展, proposed by the Brundtland Commission in 1987 and adopted by the United Nations at the 1992 Conference on Environment and Development, which was also adopted in China until the mid-2000s. ${ }^{(11)}$

In sum, if CCP leaders decided to talk about EC from the 2000s onward, it was mainly as a political response to the state's failure to protect the envi-

2. “中共中央国务院关于加快林业发展的决定” (Zhonggong Zhongyang Guowuyuan guanyu jiakuai linye fazhan de jueding, Decision of the CCP Central Committee and the State Council on Accelerating the Development of Forestry of 25 June 2003.

3. “胡锦涛在中国共产党第十七次全国代表大会上的报告. 四、实现全面建设小康社会奋斗 目标的新要求" (Hu Jintao zai Zhongguo Congchandang di shiqi ci quanguo daibiao dahui shang de baogao. Si: shixian quanmian jianshe xiaokang shehui fendou mubiao de xin yaoqiu, Hu Jintao's report to the $17^{\text {th }}$ CCP Congress. Section 4: New requirements for realising the goal of building a well-off society in an all-round way), Renmin Ribao, 25 October 2007, http://CCP.people.com.cn/ GB/64093/67507/6429846.html (accessed on 15 October 2018).

4. “中央全面深化改革领导小组下设经济体制和生态文明体制改革专项小组生态文明建设 有了顶层组织保障" (Zhongyang quanmian shenhua gaige lingdao xiaozu xia she jingji tizhi he shengtai wenming tizhi gaige zhuanxiang xiaozu shengtai wenming jianshe youle dingceng zuzhi baozhang, The Economic system and ecological civilisation construction system reform taskforce under the Central Comprehensive and Deep Reform Leading Small Group provides top-level institutional guarantee for ecological civilisation construction), Xinhuanet, 24 January 2014, http://politics.people.com.cn/n/2014/0124/c70731-24216808.html (accessed on 15 October 2018).

5. CCP Central Office (Zhonggong Zhongyang 中共中央), “国务院关于加快推进生态文明建设 的意见" (Guowuyuan guanyu jiakuai tuijin shengtai wenming jianshe de jianyi, Opinions of the State Council on accelerating the construction of ecological civilisation), Document No. 12, 25 April 2015; and the follow-up "生态文明体制改革总体方案" (Shengtai wenming tizhi gaige zongti fang'an, Comprehensive plan for an eco-civilisation system), 21 September 2015; and "关 于省以下环保机构监测监察执法垂直管理制度改革试点工作的指导意见” (Guanyu sheng yixia huanbao jigou jiance jiancha zhifa chuizhi guanli zhidu gaige shidian gongzuo de zhidao yijian, CCP Central Committee guiding opinion on experiments for reforming the vertical management for monitoring and enforcement of environmental protection institutions below the Province level), September 2016

6. According to the exchange rate (CNY/USD: 0.15015$)$ on 26 september 2017, provided by xe converter: https://www.xe.com/fr/currencycharts/?from $=C N Y \& t o=U S D \& v i e w=2 Y$ (accessed on 22 October 2018)

7. Data reported in "Environmental Inspections: Stopping the Pollution Pipeline," NewsChina, 24 Mai 2018.

8. Xi Jinping's Work Report to the 19th Party Congress “决胜全面建成小康社会 夺取新时代中国 特色社会主义伟大胜利” (Juesheng quanmian jiancheng xiaokang shehui duoqu xin shidai zhongguo tese shehuizhuyi weida shengli, Secure a decisive victory in building a moderately prosperous society in all respects and strive for the great success of socialism with Chinese characteristics for a new era), Section 3, p. 23, and Section 19, p. 50

9. Several articles of the Constitution have been amended to add EC construction, for example, Paragraph 7.

10. The Russian article translated and abbreviated by Guangming Ribao on 18 February 1985 was entitled “在成熟社会主义条件下培养个人生态文明的途径” (Zai chengshu shehuizhuyi tiaojian xia peiyang geren shengtai wenming de tujing, Cultivating the way of individual ecological civilisation under the condition of mature socialism).

11. The principle of sustainable development was embodied in the China Agenda 21 (Zhongguo 21 shiji yicheng 中国21世纪议程) adopted by the State Council in 1994 following the Rio Earth Summit. It was called a "basic state policy" (jiben guoce 基本国策) and was included in China's five-years policy development plans from 1997 onward. 
ronment, and to prevent this failure from threatening its claim to rule (Wang 2013, 2018). To become an effective political discourse, however, EC had to resonate with broader environmental and political values carried, in part, by Chinese environmental scholars.

\section{The shifting intellectual scope of ecological civilisation from the Hu-Wen to the Xi-Li administration}

This section explains how EC evolved from embodying the widely shared sense of crisis in China's development model under Hu and Wen, to becoming a confident narrative of ecological rejuvenation under $\mathrm{Xi}$ Jinping.

When ecological civilisation appeared in 2007, it was presented as a political commitment by the CCP to reform the unsustainable development model. ${ }^{(12)}$ The alarm resulted from several years of epistemic construction undertaken by researchers under the banner of "scientific development outlook" (kexue fazhan guan 科学发展观) promoted by the Hu-Wen leadership, which diagnosed both China's development and the CCP's governing capacity as threatened by growing inequalities, rampant corruption, and rising social unrest. ${ }^{(13)} \mathrm{Hu}$ and Wen's promised a new development model that would be "people-centred" (yi ren wei ben 以人为本), comprehensive, coordinated, and sustainable. ${ }^{(14)}$

The scientific community contributed abundantly to this deep questioning of the development model. The first voluminous China Environment and Development Review (CEDR Zhongguo huanjing yu fazhan pinglun 中国环 境与发展评论), published in 2004, featured many essays that openly criticised the "worship" of GDP, the weakness of regulatory institutions, and the perverse incentives embedded in China's cadre evaluation and tax systems (e.g., Shen 2011; Wang and Wang 2011). (15) The State Environmental Protection Administration itself piloted several important research programs to study how to include environmental costs in the accounting of GDP growth, and thereby change the mentality of Chinese officials. Under the leadership of the outspoken Vice-minister Pan Yue, a "rising star" in the Party, the China Environmental Culture Promotion Association (CECPA Zhongguo huanjing wenhua cujinhui 中国环境文化促进会) and the popular environmental magazine Green Leaves ( Lü ye 绿叶) were turned into platforms for advancing progressive environmental governance ideas. Pan himself was a prolific contributor. In his writings, he pointed out the injustice that allowed "the rich to consume while the poor suffered pollution" and advocated learning from the eco-socialist and eco-Marxist movements of Western countries to bring about a "socialist eco-civilisation" (shehuizhuyi shengtai wenming 社会主义生态文明) in China (Pan 2006a). The New Left (xin zuo 新左) intellectual movement, represented by scholars such as Wang Hui, also played an active role in fleshing out criticism of economic liberalism (Wang and Karl 1998). In response to some foreign scholars who presented a positive picture of China's environmental modernisation, especially the attempt to use economic instruments (Carter and Mol 2007), the political scientist Huan Qingzhi replied in 2007 that "a U-turn change, rather than minor adjustments" were necessary (Huan 2007). Following this exposure of the political factors hindering China's sustainable development, in 2005 the political theorist Yu Keping flagged the idea that building an "ecological civilisation" was a prerequisite for achieving material, spiritual, and political civilisation (Yu 2005). ${ }^{(16)}$

Adopting EC also involved a "U-turn" in the discourse that had hitherto presented binding environmental norms as disguised Western imperialism
(Economy 1997; Zhang and Barr 2013). Summoning traditional cultural values was a significant political resource to legitimate environmental protection without appearing to bow to international pressure (e.g., Niu 2010; Li H. 2012). However, the choice of cultural reference was selective, and tailored to political circumstances. Thus, EC was associated with the notion of "harmony between man and nature" (tian ren heyi 天人合一), borrowed from the Confucian repertoire, at a moment when $\mathrm{Hu}$ Jintao was opportunistically rehabilitating the concept of "harmonious society" (hexie shehui 和谐社会) to delegitimise increasingly powerful social movements (e.g., Minister Zhou Shengxian 2009). Other traditional concepts of nature-society relations such as the more eco-centred Daoist concepts of "inaction" (wuwei 无为) and "nature sanctuaries" (dongtian fudi 洞天福地) were never given equivalent discursive space. ${ }^{(17)}$

Finally, another important element of the intellectual scene of the mid2000s was the unprecedented support for civil society and for pluralising decision-making (Shambaugh 2007). Starting in 2006, China's ENGO Friends of Nature was able to edit annual China Environment Green Books (Zhongguo huanjing lüpishu 中国环境绿皮书) with the help of the Chinese Academy of Social Sciences, giving unprecedented recognition to environmental activist voices. ${ }^{(18)}$ Pan Yue himself came out on the side of protestors in the landmark mobilisation against the construction of a PX plant in Xiamen in 2007 and led three consecutive "storms" of environmental impact assessments inspections (huanping fengbao 环评风暴) that resulted in stalling more than 110 large-scale industrial projects worth 112.3 billion yuan (16.4 billion dollars) (19) between 2005 and 2007.

While these actions earned Pan Yue the respect of environmental civil society actors, it also made him many powerful enemies, who came after him as soon as the political climate changed in the wake of the 2008 global economic crisis (Guo 2015). In a context of mounting anxiety over the domestic impacts of the global recession, (20) Pan Yue was silenced, and the New Left Journal Dushu 读书 was closed (Frenkiel 2011). While academics continued to publish on EC (Huan 2016), references to eco-socialism and eco-Confucianism disappeared from the official discourse (Geall and Ely 2017). Instead, official discourse focused on green growth, starting with the

12. "Ecological civilization," China Daily, 24 October 2007, http://www.chinadaily.com.cn/opinion/ 2007-10/24/content_6201964.htm (accessed on 15 October 2018).

13. “中共中央关于加强党的执政能力建设的决定” (Zhonggong Zhongyang guanyu jiaqiang dang de zhizheng nengli jianshe de jueding, CCP decision on enhancing the Party's ruling capacity) issued in September 2004.

14. China Daily editorial of 30 March 2004, http://www.people.com.cn/GB/shizheng/8198/32784/ 32788/2418669.html (accessed on 20 February 2018).

15. The first volume was put together in 2001 but was published only in 2007 together with the third volume. The International Institute for Sustainable Development (IISD) sponsored an English translation in 2011 (Keeley and Yisheng 2011), followed by Brill Press (Zheng and Liang 2016)

16. As of 2018, it had been downloaded 7,088 times from the CNKI database and cited 788 times.

17. “洞天福地与生态环保” (Dongtian fudi yu shengtai huanbao, Dongtian Fudi and ecology). Speech at the 4th International Workshop on Daoism teachings organised by the China Biodiversity Conservation and Green Development Foundation on 21 March 2017. http://www.cbcgdf.org/ NewsShow/4856/1760.html (accessed on 15 October 2018)

18. The English editions were published by Brill under the title The China Environment Yearbooks and edited by reputable foreign academics such as Judith Shapiro, Alex Wang, and Andrew Mol. See Brill's webpage http://booksandjournals.brillonline.com/content/series/the-chinese-academy-ofsocial-sciences-yearbooks-environment (accessed on 15 October 2018).

19. Conversion CNY/USD: 0.14611 on 26 December 2008 according to xe converter: https://www.xe.com/fr/currencycharts/?from $=C N Y \& t o=U S D \& v i e w=10 Y$ (accessed on 22 November 2018)

20. “政府工作报告解读:4万亿是'保八'最直接推动力" (Zhengfu gongzuo baogao jiedu: 4 wanyi shi "baoba" zuizhijie tuidongli, Government Work Report Interpretation: 4 Trillion is the most direct driving force to guarantee 8 percent GDP growth), Xinhua, 7 March 2009, http://www.gov.cn/ 2009lh/content_1253269.htm (accessed on 15 October 2018). 
endorsement of the international concept of low-carbon economy (LCE ditan jingji 低碳经济) by President Hu Jintao at the Asia Pacific Economic Forum (APEC) summit in 2009. Hu and Wen's second term ended amid rising environmental unrest and severe criticisms that they had failed to transform China's economic development model (Wang 2018). While Wen Jiabao urged local officials to "use an iron hand" (caiqu tie de shouwan 采取铁的 手腕) to achieve their 11th FYP pollution targets in December 2010, (21) Hu Jintao passed on the task of reforming the industrial model to his successor Xi Jinping.

This was the purpose of Hu's report to the 18th Party Congress, which provided the first substantial description of "ecological civilisation construction." (22) In its wake, from 2013 onward Xi Jinping himself became the main original producer of political discourse on EC (Xi 2014), (23) diffused and commented on in social media, (24) traditional Party magazines such as Qiuzhi 求知 and Xuexi shibao 学习时报, (25) as well as in a new magazine entitled China's Ecological Civilization (Zhongguo shengtai wenming 中国 生态文明) published by a new Ecological Civilisation Research and Promotion Association (CECRPA) bringing retired officials, scientists and businesses together. (26) Unlike his predecessors, who had conceived of the environmental crisis as a social and political threat with insoluble global connections, $\mathrm{Xi}$ Jinping made it a positive narrative, a key component of the China dream (Zhongguo meng 中国梦) and of the New Era (xin shidai 新时代) of rejuvenation for the Chinese nation. The most repeated quote from Xi Jinping on EC states that "green waters and clear mountains" (lüshui qingshan 绿水青山) will provide "gold and silver hills" (jinshan yinshan 金山银山), synonym of prosperity, forever (Huang 2015). ${ }^{(27)}$ As critical observers have noted, this vision reconciles EC with Western theories of ecological modernisation and the popular environmental Kuznet curve, (28) which promises environmental betterment once industrialisation and urbanisation is realised (Chen 2012; Lord 2018). Chinese theorists have even taken the evolutionary logic a step further, by portraying EC as the next step in the evolution of the world after the primitive civilisation (yuanshi wenming 原始文明), the agricultural civilisation (nongye wenming 农业文 明), and the industrial civilisation (gongye wenming 工业文明) (Oswald 2014; Ke 2013; Pan 2016).

On the political side, earlier emphasis on opening governance to civil society have given way to the promotion of a top-down model of ecological transition led by the Party (J. Chen 2017). ${ }^{(29)}$ Notions of "top-level design" (dingceng sheji 顶层设计) and daobi tizhi 倒逼体制—a synonym for structural coercion (Hu 2013) _became buzz words. ${ }^{(30)}$ Having implemented the series of recentralising reforms described above, in May 2018 Xi Jinping exhorted officials to "concentrate power under the leadership of the CCP to win the tough battle against pollution and achieve an ecological civilisation." (31) As Pan Jiahua (2016) remarked, in this regard Xi's EC is radically different from that advocated by the American political comparatist Roy Morrison in the 1990s, for whom ecological civilisation was "a call for democracy" and not a call "for better management or stronger authority" (Morrison 1995).

Finally, Xi's EC discourse has exacerbated trends towards political and cultural chauvinism. Exalted praise of the ecological wisdom of China's ancient culture, put against the evil of imported Western industrialism, have become mainstream (Gaffric and Heurtebise 2013; Heurtebise 2017). For instance, in 2015 an editorial in People's Daily claimed that China's "profound cultural heritage of loving and protecting nature" was "beyond reach for other cultures." (32) Along similar lines, while the 2000s had questioned the Chinese development model, the new discourse re-instated the outdated leitmotiv inherited from the Cold War that "China must not imitate the development model of the West" (e.g. Pan 2016). Some commentators have even brandished EC as a symbol of a "China Model" supporting its international soft power (e.g. Zhang 2008). In line with this agenda, in 2016 the CCICED - a boundary institution created in 1992 to institutionalise communication between the Chinese leadership and the international community on sustainability-decided that its mission was no longer to bring sustainability knowledge to China, but rather to help define "how China can become a leader on environmental and development concerns" (CCICED 2016).

In sum, this section has shown that the "Socialist Ecological Civilisation Construction with Chinese Characteristics," as the 19th Party Congress put it, has blended references to different ideologies (si chao 思潮) ${ }^{(33)}$ over time,

21. “温家宝抓好七项工作确保实现十一五节能减排目标” (Wen Jiabao zhua hao qi xiang gongzuo quebao shixian shiyiwu jie neng jianpai mubiao, Wen Jiabao: Get seven pieces of work done, ensure the realisation of the "11th five-year plan" energy savings, emissions reductions targets), Xinhua, 5 May 2010, http://finance.ifeng.com/news/20100505/2148934.shtml (accessed on 15 October 2018).

22. “胡锦涛十八大报告. 八 、大力推进生态文明建设” (Hu Jintao shiba da baogao. Ba, dali tuijin shengtai wenming jianshe, Hu Jintao's $18^{\text {th }}$ Work Report. Section 8: Vigorously promote the construction of ecological civilisation), China.com.cn, 20 November 2012, http://news.china.com.cn/ politics/2012-11/20/content_27165856_7.htm (accessed on 15 October 2018); and the English translation of the report's section entitled "Making great efforts to promote ecological progress," Xinhua, 19 November 2012, http://en.people.cn/102774/8024786.html (accessed on 15 October 2018).

23. According to Xinhua, by 2015 Xi had spoken about EC more than 60 times. Xinhua, 10 March 2015, http://politics.people.com.cn/n/2015/0310/c1001-26666629.html (accessed on 15 October 2018)

24. For instance, the public Wechat accounts Huanbao zhijia 环保之家 and Huanjing baohu 环境保护

25. Numerous articles on the theme "ecology is civilisation" (shengtai xing ze wenming xing 生态兴 则文明兴) and the "new ecological civilisation era" (zou xiang shengtai wenming xin shidai 走 向生态文明新时代) can be found by browsing the websites of Study Times, Journal of the Central Party School (Xuexi shibao, Zhonggong Zhongyang dangxiao zhuguan 学习时报, 中共中央党 校主管), http://www.studytimes.cn/ (accessed on 15 October 2018) and qstheory.cn (Qiushi wang 求是网), http://www.qstheory.cn/ (accessed on 15 October 2018).

26. See the website of CECRPA (Zhongguo shengtai wenming yanjiu yu cujin hui 中国生态文明研 究与促进会), http://www.cecrpa.org.cn/index.htm (accessed on 15 October 2018).

27. The quote was even an exam question in the National Examination of June 2018. See "新鲜出 炉! 今年高考作文题大全 你觉得哪篇最难写? ” (Xinxian chulu! Jinnian gaokao zuowen ti daquan, ni juede na pian zui nan xie? Freshly baked! All essay questions from this year's college entrance examination. Which one do you think is the most difficult to write?), CCTV.com, 7 June 2018, http://m.news.cctv.com/2018/06/07/ARTIHZmINyPsG6xYX8Wb60Ff180607.shtml (accessed on 15 October 2018).

28. The environmental Kuznets curve theory postulates an inverted-U-shaped relationship between different pollutants and per capita income: pollutant emissions increase gradually as the economy grows, peak when industrialisation is completed and decline afterward. MEP's Chen Jining used it in his 2016 Press Conference. "Transcript of Minister Chen Jining's press conference," CCICED website, 9 March 2016, http://www.cciced.net/cciceden/NEWSCENTER/LatestEnvironmentalandDevelopmentNews/201603/t20160309_82663.html (accessed on 15 October 2018).

29. This speech should also be read in the context of Chen's imminent promotion to Mayor of Beijing.

30. Hu Zi describes daobi as meaning "being compelled to act" (bu yu wei zhi er budebu weizhi 不欲 为之而不得不为之).

31. “习近平出席全国生态环境保护大会并发表重要讲话” (Xi Jinping chuxi quanguo shengtai huanjing baohu dahui bing fabiao zhongyao jianghua, Xi Jinping's opening speech to the National Environmental Protection Conference), Xinhua, 19 May 2018, http://www.gov.cn/xinwen/201805/19/content_5292116.htm (accessed on 15 October 2018).

32. People's Daily editorial reproduced on China Climate Info-net, "中国生态文明建设具有制度和 文化优势” (Zhongguo shengtai wenming jianshe juyou zhidu he wenhua youshi, China's ecological civilisation construction has institutional and cultural advantages), Renmin Ribao, 6 March 2015, http://www.ccchina.org.cn/Detail.aspx?newsld=51282\&TId=182 (accessed on 15 October 2018).

33. People's Daily article of 21 January 2013, “盘点 : 2012中外十大思潮的特点与走向一一本年 度十大思潮调查结果与简要分析" (Pandian: 2012 Zhongwai shi da sichao de tedian yu zouxiang—-benniandu shi da sichao diaocha jieguo yu jianyao fenxi, Inventory: Top ten ideological trends in China and abroad in 2012 - The results and brief analysis of the top ten thoughts of the year), Renmin Ribao, 4 February 2013, http://theory.people.com.cn/n/2013/0204/c11285120428805.html (accessed on 15 October 2018). 
Graph 2 - Comparing the publication trends of articles on "sustainable development" and articles on "ecological civilisation" between 2000 and 2017.

\section{ALL CNKI JOURNAL ARTICLES}

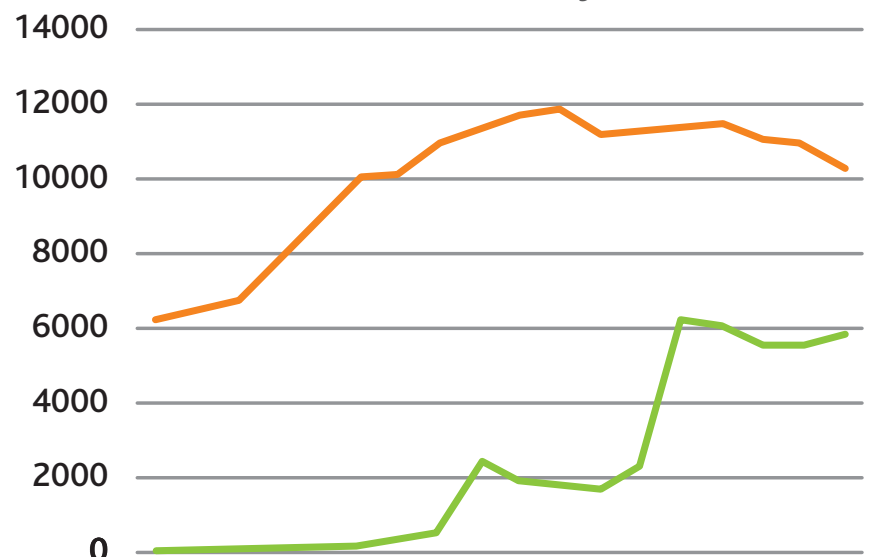

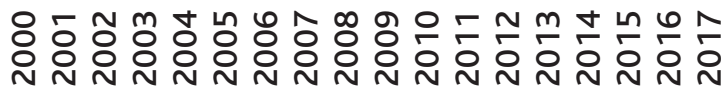

\section{Ecological}

Civilisation

\section{Sustainable \\ Development}

CSSCI JOURNAL ARTICLES

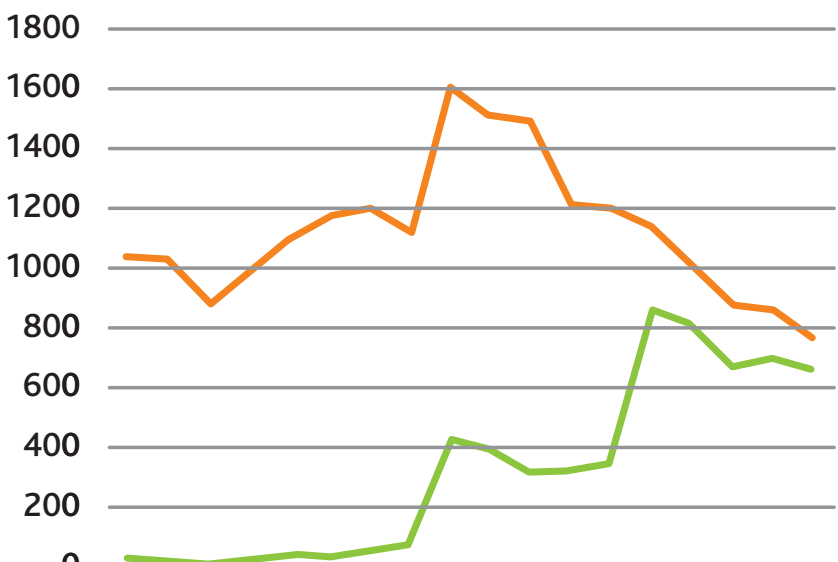

Source: Compiled by the author from the CNKI database

Note: For this graph the CNKI database for academic journals (qikan 期刊) was searched for articles with "sustainable development" (kechixu fazhan 可持续发展) and then with "ecological civilisation" (shengtai wenming 生态文明) in their titles. Then a similar search restricted to CSSCl journals was performed.

reflecting the values and power practices of successive leaderships. Whereas Chinese academics have contributed to its construction by interpreting political discourses and have tried to influence policy-making by speaking the language of power (Holbig 2018), critical inputs have sharply diminished since the CCP and its leaders decided to make EC the end goal and a symbol of their unquestionable leadership of China's destiny.

\section{Ecological civilisation in academic research: Ideological ethos and academic resilience}

If academic inputs to the $\mathrm{EC}$ discourse have decreased since this discourse has been marshalled by the CCP propaganda throughout Chinese society, then to what extent has scientific research on sustainability been influenced by it? A bird's-eye view on the research produced in the past 15 years, displayed in Graph 2, seems to indicate a significant impact. Since 2007, the number of articles on EC has increased, while the number of articles on "sustainable development" has decreased.

However, this broad trend hides a more complex and nuanced intellectual landscape. This section discusses how the spreading of official propaganda has coexisted with genuine theoretical ambitions, as well as with the repackaging of existing critical arguments in trendy political terminology.

\section{The impact of ecological civilisation on the growing field of Chinese sustainability research}

The rise of the political discourse of EC since the mid-2000s has intertwined with the rapid development of Chinese academic research on ecology, displayed on Graph 3. Besides genuine academic interest and the relative political space opened by the "scientific development" mantra, another essential factor has been the significant increase in public research funding going into social sciences (Zhang 2008; Holbig 2014).
Public funding institutions such as the National Planning Office for Philosophy and Social Sciences (NPOPSS) have been missioned by the CCP to support the development of scientific research, but also, more specifically, to "promote the study and development of Marxist theory and to build an innovation system in philosophy and the social sciences," (34) which has entailed an emphasis on topics linked to Party theory (Holbig 2014). An analysis of the projects funded by the NPOPSS's prestigious National Social Sciences Fund (NSSF guojia sheke jijin 国家社科基金) since 2005, displayed on Graph 4 and 5, shows that indeed, in the field of ecology the NSSF has tended to favour projects that follow the official terminology.

Furthermore, a closer examination of the projects' discipline reveals that a majority of EC-labelled projects have been sourced from Marxism studies and Philosophy, ${ }^{(35)}$ which have been most closely associated with the promotion of "Party theory" innovations. Conversely, these findings indicate that the popularity of $\mathrm{EC}$ in academic research may have increased partly as a result of instrumental calculations that labelling a project with $\mathrm{EC}$, a known Party theory concept, would increase chances of success (Holbig 2014). Several EC-labelled projects focus on wider governance topics such as "the ecological transformation of the rule of law" (Major Project No. 14ZDC030, 2015) or "reform of the public finance system" (Major Project No. 15ZDB158, 2015). However, this trend is not absolute and the NSSF has also funded non-EC labelled projects on, e.g. "environmental governance" and "pollution."

34. “胡锦涛十八大报告. 二、夺取中国特色社会主义新胜利” (Hu Jintao shiba da baogao. Er duoqu Zhongguo tese shehuizhuyi xin shengli, Hu Jintao's report at the $18^{\text {th }}$ Party Congress's Section 2 on strengthening core socialist values), China.com.cn, 20 November 2012, http://news.china.com.cn/politics/2012-11/20/content_27165856_3.htm (accessed on 15 October 2018).

35. In China philosophy is commonly divided into three categories: Marxist philosophy, traditional Chinese philosophy and Western philosophy. The first category overlaps with Marxism studies. 


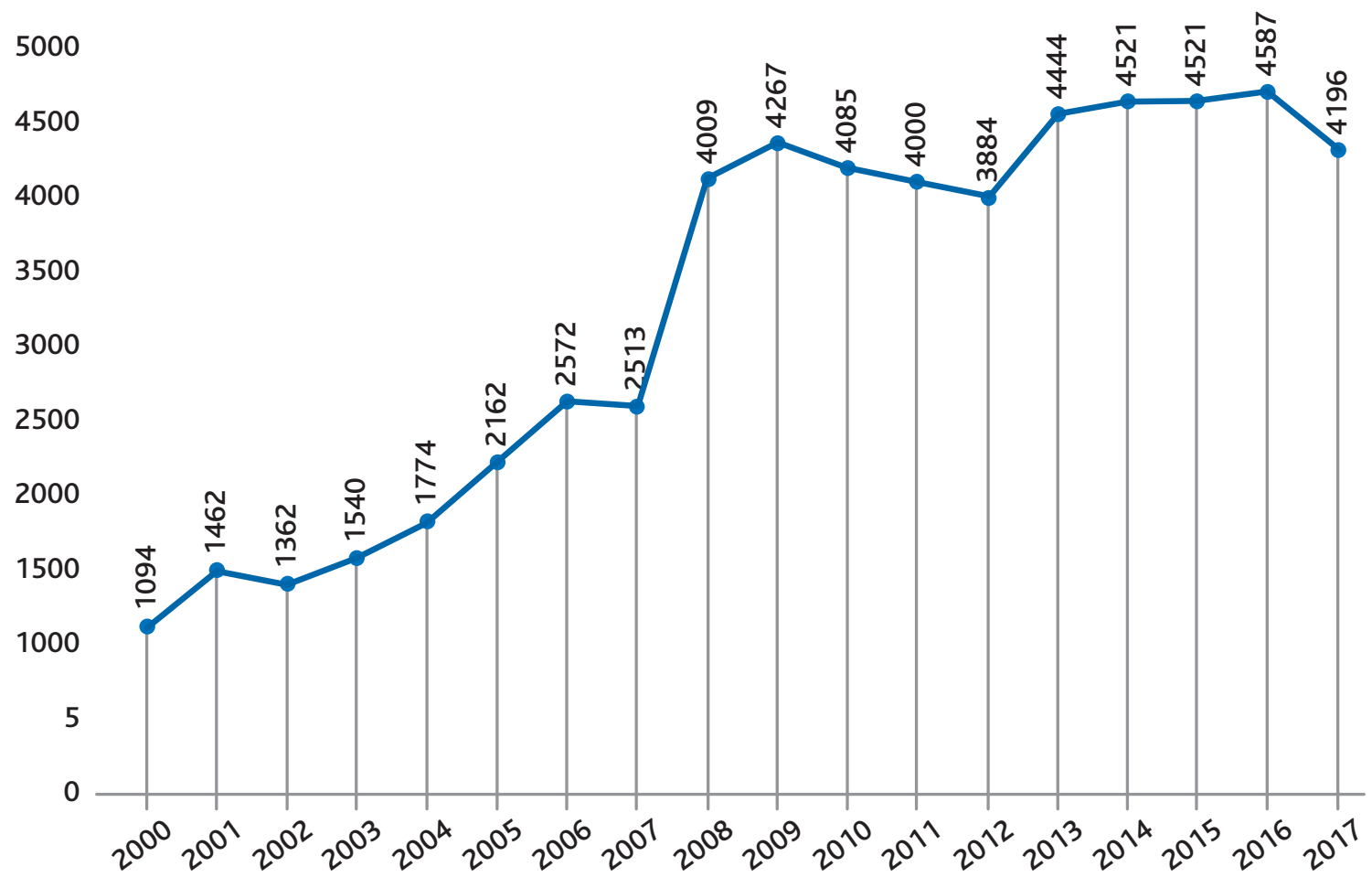

Source: Compiled by the author from the CNKI database

Note: For this graph the CNKI database was searched for articles associated with topics (zhuti 主题) of ecology (shengtai 生态) and environmental protection (huanjing baohu 环境保护), among the top social science journals included in the Chinese Social Sciences Citation Index (CSSCI).

\section{Academic uses of ecological civilisation and their theoretical limits}

The increasing popularity of EC in academic works does not necessarily imply a surrendering of sustainability research to CCP ideologues, even though those who aspire to engage with theories of sustainability have been increasingly constrained by the necessity to articulate their arguments in relation with the official ideology.

Firstly, it is important to acknowledge that, even if an abundance of Party theory articles on EC have barely done more than repeat the Party line, many respected Chinese academic publications have not bowed to the official terminology. For instance, none of the six volumes of the China Environment and Development Review mentioned earlier have used the term EC, and China Environmental Green Books only mentioned EC once in the title of the latest volume's introduction - and even there it is merely a catchword, while the report's content focuses on the internationally emerging concept of anthropocene (translated renlei shi 人类世). ${ }^{(36)}$ This variability in academic uses of EC is further attested by comparing two influential academic environmental journals: Environmental Protection, (37) affiliated with the Ministry of Environmental Protection, and the Chinese Journal of Population Resources and Environment, ${ }^{(38)}$ which was created in 1992 to support the implementation of Agenda 21 and has been independently managed by a consortium of universities under the remote tutelage of the Science and Technology Ministry. ${ }^{(39)}$ As shown in Graph 6, the former has followed the political terminology much more closely than the latter, even though since 2013 the use of EC has gained ground there are well.

Secondly, academics have used the term EC without pursuing the same objectives or investing similar meanings in it. This diversity can be ap- praised from the perspective of the researchers' disciplinary background. Hence, in China as elsewhere, ecology has been a cross-disciplinary matter. As Graph 7 illustrates, even though environmental economics and policy research has dominated the field, law, philosophy, and eco-Marxism studies have grown significantly since the 2000s, ${ }^{(40)}$ and, as noted in the introduction, environmental sociology, environmental history, and environmental politics have also emerged, albeit much more recently (Dong 2010). China's most famous sociologist, Prof Fei Xiaotong, raised attention to environmental pollution as early as 1984 (Fei 1984), but it is only in 2009 that the first research institute dedicated to environmental sociology was created at Renmin University. ${ }^{(41)}$ Political ecology, one of the most lively fields of environmental scholarship internationally, has not been able to take root in China, most likely due to the political sen-

36. The general report is entitled “生态文明建设：亟须综合性配套与措施落地” (Shengtai wenming jianshe: ji xuzonghe xing peitao yu cuoshi luodi, Ecological civilisation construction: It is urgent to adopt comprehensive implementation measures). "Anthropocene" was first put forward by Crutzen in "Ceology of mankind" published in Nature in 2002. It designates "a geological epoch when humans dominate the shaping and reshaping of the planet."

37. Webpage of the journal Environmental Protection (Huanjing baohu 环境保护): http://www.hjbhzz.com/index.php?m=page\&a=about\&id=6 (accessed on 15 October 2018).

38. Webpage of the journal China Population Resources and Environment (Zhongguo renkou. Ziyuan yu Huanjing 中国人口.资源与环境): http://www.cpre.sdnu.edu.cn/WKC/WebPublication/wkTextContent.aspx? navigationContent $\mid \mathrm{D}=\mathrm{cc} 78 \mathrm{~d} 89 \mathrm{~d}-218 \mathrm{~b}-4266-\mathrm{a} 1 \mathrm{fd}-\mathrm{bf} 321 \mathrm{f6} 626 \mathrm{f} 7 \mathrm{~d} \& \mathrm{mid}=\mathrm{zgrz}$ (accessed on 15 October 2018).

39. Webpage of the Ministry of Science and Technology on China's Agenda 21 implementation and management center (Zhongguo 21 shiji yicheng guanli zhongxin 中国21世纪议程管理中心) http://www.most.gov.cn/zzjg/zzjgzs/zzjgsy21sj/index.htm (accessed on 15 October 2018)

40. Wang Zhihe's review of eco-Marxism in China confirms this data. See Wang (2012).

41. Webpage of Renmin University "Chinese Environment Sociology" (zhongguo huanjing shehuixue wang 中国环境社会学网) http://ces.ruc.edu.cn/more.php?cid=311 (accessed on 15 October 2018). 


\section{All National Social Sciences Projects}

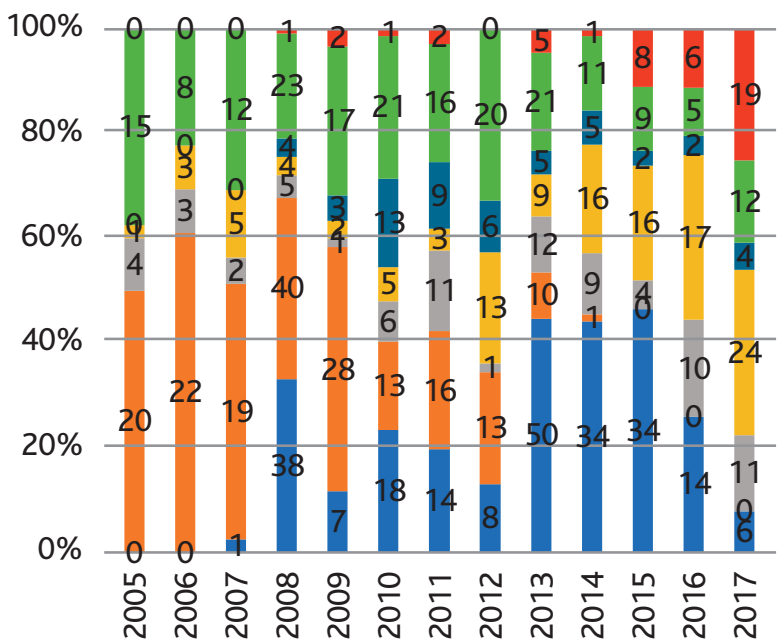

Environmental Governance

- Sustainable Development

- Climate Change

Pollution

Environmental Protection

- Scientific Development

- Ecological Civilisation

\section{Major National Science Projects}

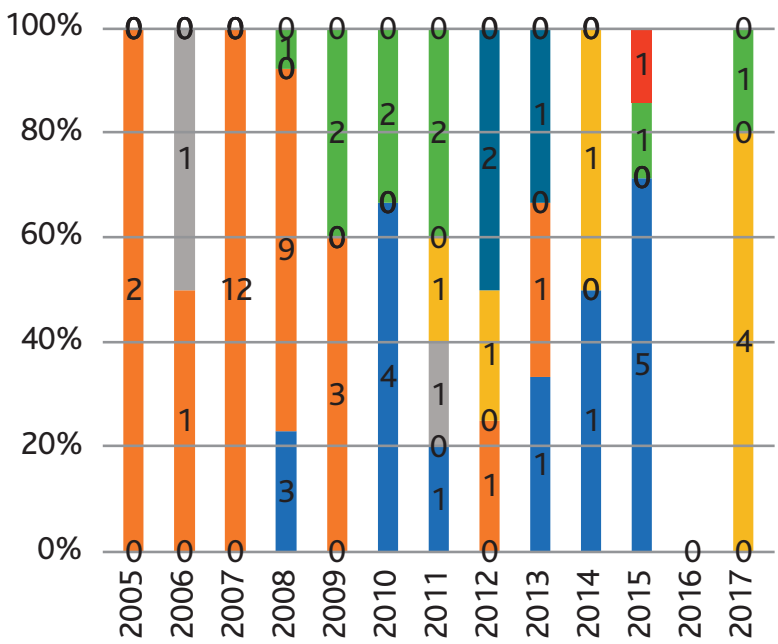

- Environmental Governance

- Sustainable Development

- Climate Change

Pollution

Environmental Protection

- Scientific Development

- Ecological Civilisation

Note: National research project grants (guojia sheke jijin 国家社科基金), major projects (zhongda xiangmu 重大项目).

\section{Graph 5 - Disciplinary categorisation of NSSF projects on ecological civilisation}

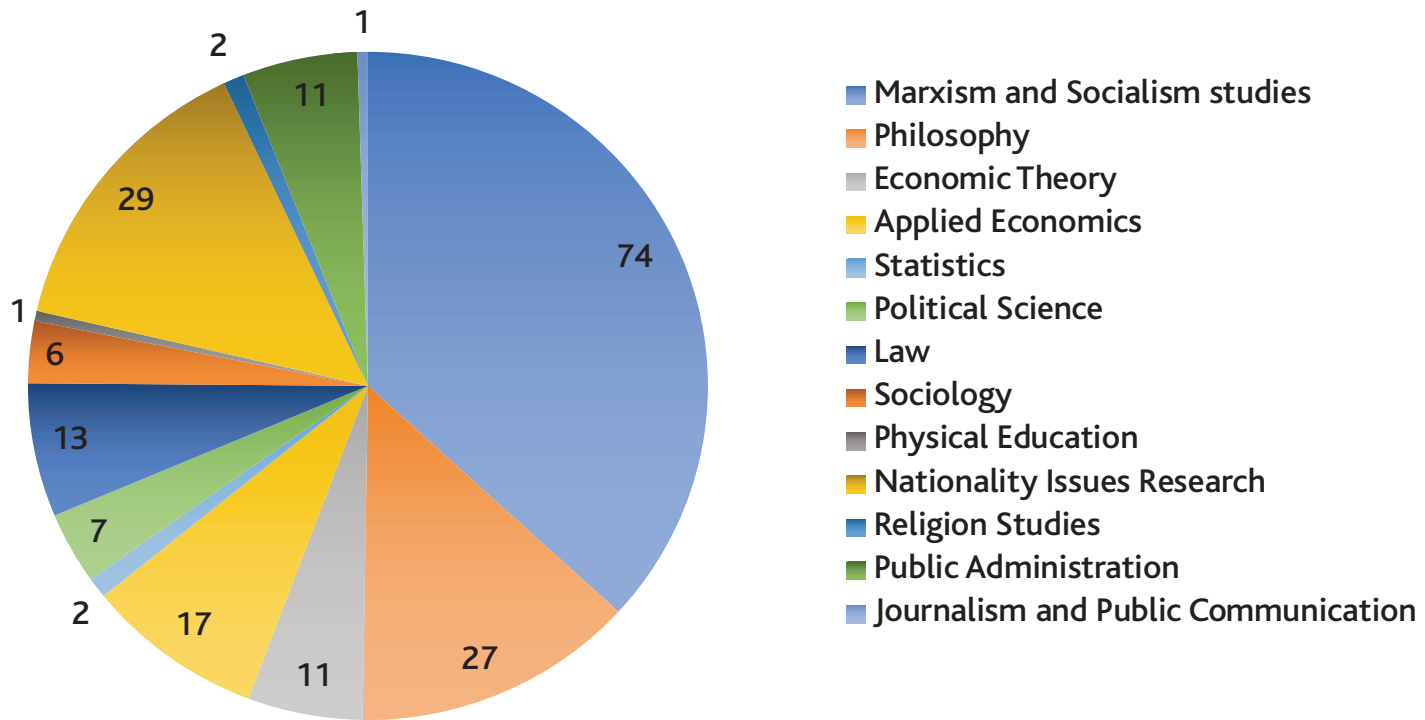

Source: Compiled by the author from National Planning Office of Philosophy and Social Science database (http://fz.people.com.cn/skygb/sk/index.php/Index/seach). Note: The keyword "ecological civilisation" was searched for each scientific discipline recorded in the database. Twelve disciplines that had no record, including relevant ones such as Chinese history and Party history, are not included in the graph.

sitivity of its "political commitment to social justice and structural political change" (Bridge et al. 2015; Yeh 2015; Lord 2018). Nonetheless, the diversification of disciplinary interests in ecology has sustained the coexistence of various epistemologies, theories, and projects under the EC label, some of which implicitly or explicitly challenge parts of the political propaganda.

An interesting way to demonstrate this relative pluralism, while also pointing out its limits, is to examine the six articles published by Social Sciences 
Graph 6 - Disciplinary categorisation of NSSF projects on ecological civilisation

Concepts use in the Journal Environmental Protection

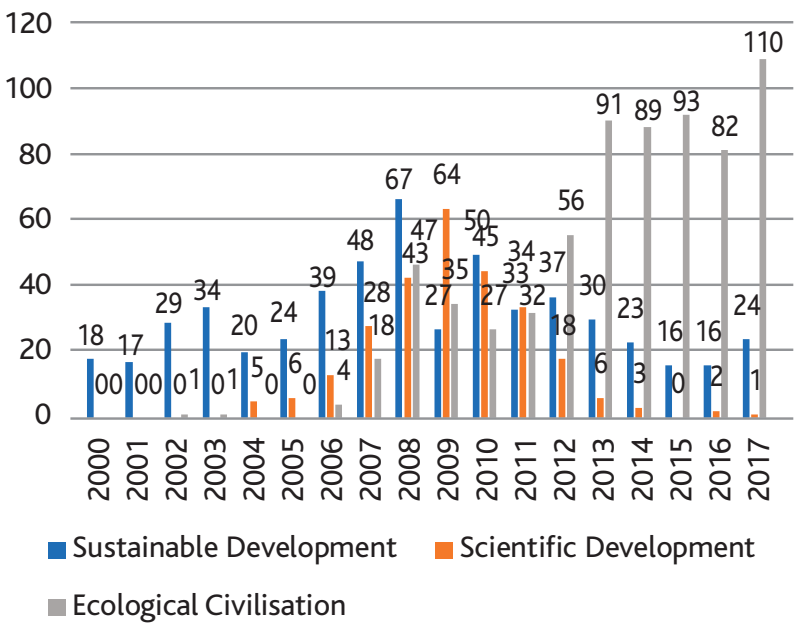

Concepts use in the Journal China Population, Resources and Environment

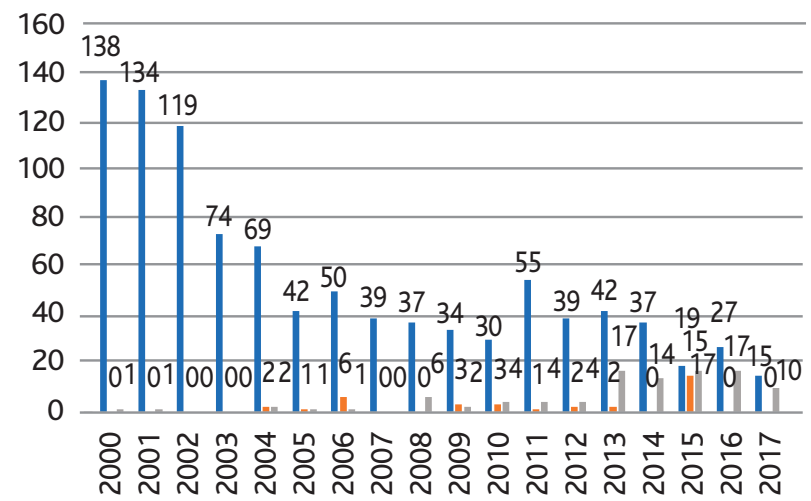

- Sustainable Development _ Scientific Development

Ecological Civilisation

Source: Compiled by the author from the CNKI database

Note: For these graphs the two journals were successively searched by year for the topics of sustainable development (kechixu fazhan 可持续发展), scientific development (kexue fazhan 科学发展), and ecological civilisation (shengtai wenming 生态文明).

Graph 7 - CSSCl journal articles on "ecology" and "environmental protection" in disciplinary journals

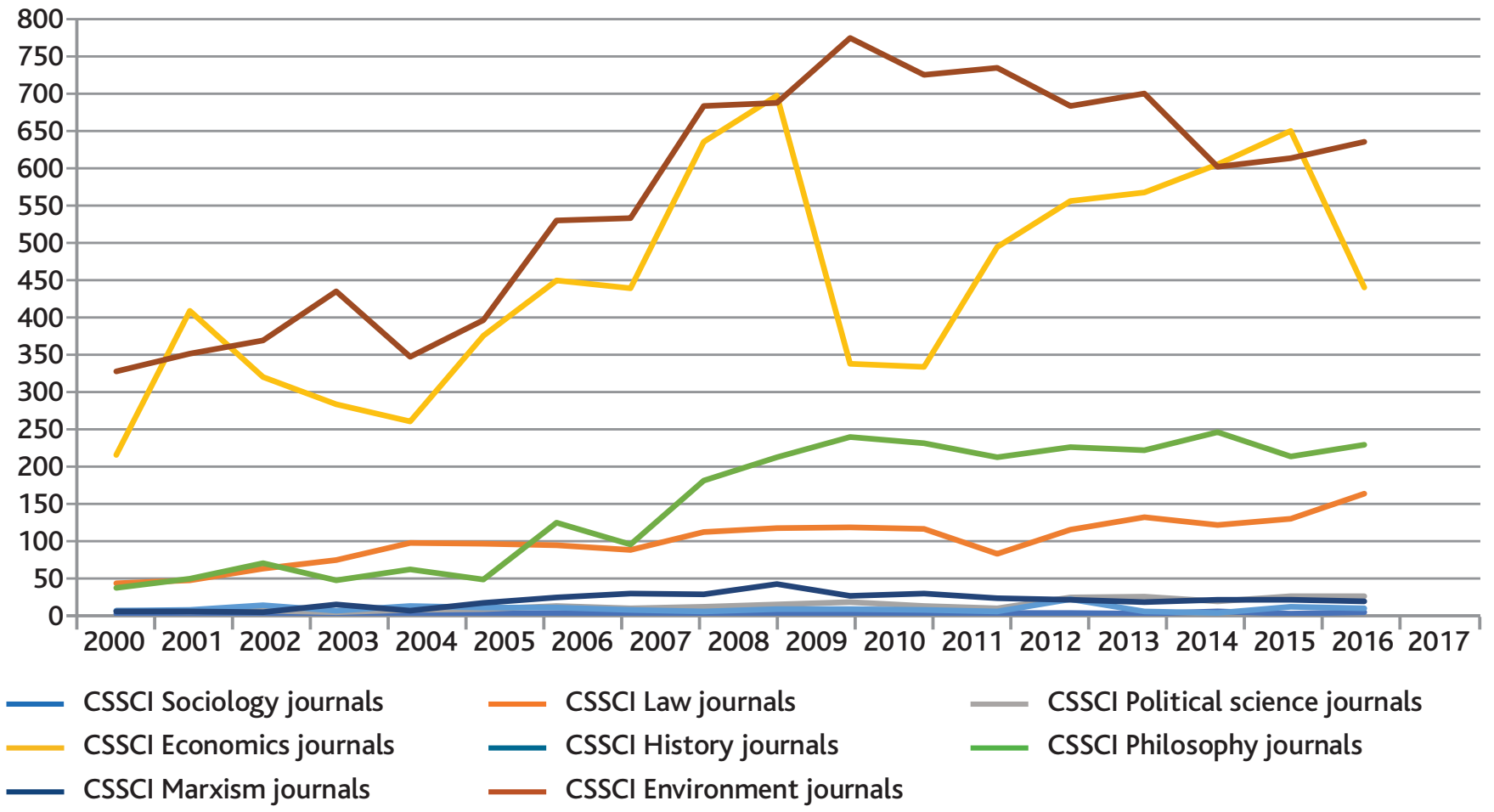

Source: Compiled by the author from the CNKI database

Note: For this graph the CNKI database was searched for articles associated with the topics (zhuti 主 题) of ecology (shengtai 生态) and environmental protection (huanjing baohu环境保护), among the top social science journals included in the CSSCl disciplinary journals selected by keywords in the journal's name (shehuixue 社会学, fa 法, zhengzhi 政治, jingji 经济, lishi 历史, zhexue 哲学, Makesi 马克思, huanjing 环境), which indicates the discipline they represent. This method, although not extremely accurate, nevertheless indicates trends.

in China in the 2013 special issue on "Ecological Civilisation and Beautiful China" (shengtai wenming yu meili Zhongguo 生态文明与美丽中国) mentioned in the introduction. The editors wanted to mark the inclusion of EC in the CCP Constitution ${ }^{(42)}$ and invited establishment scholars from different disciplines to discuss the theoretical implications of the concept.
What is striking is that beyond apparent harmony with the direction taken by the CCP, these authors emphasise different elements of the official

42. The English version is translated from “生态文明与 '美丽中国'笔谈” (Shengtai wenming yu 'meili Zhongguo' bitan) published by Zhongguo shehui kexue 2013(5). The Chinese issue had only five articles; the most propagandistic one, by Zhang and Wang, was added to the English edition. 
rhetoric, add some of their own, and even implicitly challenge parts of its assumptions, claims, and practices.

For instance, the lawyer Lü Zhongmei (2013) connects the evolutionary narrative of EC with a parallel narrative of legal progress, which should end, in her view, with full-fledged rule of law (another long-time promise of the CCP). Lü continues by reiterating the advocacy developed by Chinese environmental lawyers for decades, including the need to improve and unify legislation, to hold polluters and the administration accountable, and to uphold citizens' right to information and supervision (Wang 2011; Wang 2014). However, the article does not go as far as talking about environmental rights, nor does it explain how EC can succeed where decades of environmental law-making have failed (Wang et al. 2014).

Similarly, the article by economist Pan Jiahua endorses both the teleology of civilisational development that promises a future of eternal green prosperity, and the top-down ecological transition model to be implemented by "green" technocrats (Pan 2013; Marinelli 2018). However, in line with his background in environmental economics and decades of advocacy in international organisations, ${ }^{(43)}$ Pan insists on the existence of rigid environmental limits that must be respected, which leads him to formulate a strong criticism of CCP-led modernisation projects such as the south-north water diversion canals (Pan 2013). Nonetheless, Pan's economic theory of EC has nothing to say about the politics of vested interests, nor does it provide a clear understanding of the social disruptions that the large-scale industrial transformation he advocates may entail.

In sharp contrast with the first two contributions, the articles by sociologist Wang Xiaoyi and historian Zou Yilin maintain much more distance with the master-plan and grand narrative of EC. While endorsing EC as an end goal, both draw on their disciplinary perspective to defend a decentralised and pluralist model of ecological transition that effectively takes into account the diversity of local situations. While Zou warns that some of China's most catastrophic environmental disasters were caused by excessively centralised regimes (Zou 2013), Wang argues that EC can only succeed if it includes grassroots communities (Wang 2013). Wang specifically criticises the national conservation programs implemented in Inner Mongolia, which, he argues, deprived local communities of their livelihood and pushed herdsmen to adopt illegal and even more environmentally harmful grazing practices. With his insistence on social justice and the importance of the local, Wang's epistemology comes closest to that of political ecology. He writes from a distinct trend in Chinese sociology, which has overtly if not outspokenly sided with the disadvantaged (Rocca 2008). Yet, his arguments are carefully framed as policy advice, rather than outright criticism, and instrumentally draw on other elements of the CCP's political rhetoric, such as the elimination of poverty and the inclusion of ethnic minorities.

Zou Yilin's article also challenges EC's grand narrative by questioning the pertinence of understanding man-nature relations through the unique lens of factors of production. Like other thinkers in this emerging discipline in China (e.g. Bao 2004; Zhao 2011), he argues that a realistic comprehension of man-nature relationships can only emerge from "a truthful knowledge of history" (Zou 2013). His perspective is ontologically incompatible with the last article of the special issue written by the Marxist scholars Zhang Xunhua and Wang Yan —included only in the English version-which interprets EC exclusively in terms of factors of production and the pursuit of socialist modernisation (Zhang and Wang 2013).

Zhang and Wang's article is not representative of all the Chinese research on eco-Marxism and eco-socialism. As shown above, eco-Marxism and eco-socialism, which has been a fruitful resource for critical political economy research on development and environment internationally, has seen a rapid development in China. To a large extent, it has contributed to broadening the scope of and regenerating the research undertaken at the well-funded mandatory Schools of Marxism. ${ }^{(44)}$ Nonetheless, this article shows some of the core theoretical and political challenges of Chinese eco-Marxism and eco-Socialism, ${ }^{(45)}$ among which a significant one is to, transcend the predicament of Marxism studies as the beholder of China's "socialist state" official ideology, and to reconnect eco-Marxism critics of capitalist development with the critical review of China's own development experience, building on the aborted efforts by the New Left in the 2000s. The difficulty of this exercise is most visible in the way that Zhang and Wang claim not only that EC is "urgently needed" for China to "avoid the old route of Western industrialisation," as if China's industrialisation had not already caused dramatic environmental damage, but also in the way they uphold the ideological argument that in a socialist country like China, environmental problems cannot come from capitalism-as is the case in the West-but must stem from people's lack of awareness and value of nature (Gao and Guan 2012). In other words, the criticism of "industrial civilisation" to which these proto-Marxists subscribe silences more specific criticism of the political and economic institutions that enabled ecological destruction to go unchecked in China for decades. In the special issue, the article by the philosopher Wan Junren expressly excuses these past behaviours as "unavoidable" due to China's conditions of under-development, before praising the new resolve to pursue ecological civilisation as "the most solemn and well-chosen political commitment" to transform society in line with the new awareness of ecological limits (Wan 2013).

However, some Chinese political thinkers within the establishment have taken a more critical approach towards socialist ideology. They have developed genuinely critical reflections of existing theories of sustainable development, and have tried to understand not only "how China's historical experience may have hindered the expansion of intellectual enlightenment, technological development, and modern consciousness, but increasingly also the extent to which China's heritage may offer a critical alternative to the environmental, social, and cultural costs of the Chinese state's market development model (Jenco 2013). Two notable, albeit different reflections have been developed by Professor Huan Qingzhi at Peking University's School of Marxism, and by Professor Whang Zhihe at the Institute of Postmodern Development in China.

In an extension of the reflections initiated with Pan Yue in the mid-2000s, Huan Qingzhi has developed the premises of a "left-green" (hong lü lianmeng 红绿联盟) theory of "socialist eco-civilisation," which aims at making China part of a global, anti-capitalist "social-ecological transformation" (Huan 2014, 2016a). For Huan, ecological civilisation is a modernisation project that is "mildly eco-centred," since it puts "civilisation," i.e. society, at the centre, but includes interdependent relationships with nature in its organisation (Huan 2015). ${ }^{(46)}$ Citing the American Marxist John Bellamy

43. Pan Jiahua has been head of UNEP and coordinator for the IPCC

44. Xiao Wei, "Full Marx for Creativity: Reforming Political Education in China," Sixth Tone, 24 July 2017, http://www.sixthtone.com/news/1000561/full-marx-for-creativity-reforming-political-education-in-china (accessed on 15 October 2018).

45. For a review of eco-Marxism in China, see the article by Wang Zhihe (2012).

46. In this way Huan's ontological position is very close to that of Pan Jiahua, for whom "civilisation" also entails a focus on the human world and its responsibility towards nature. 
Foster and the German left-wing political scientist Ulrich Brand, Huan's key criticism focuses on global economic liberalism and the indefinite search for profit, including under the disguise of "sustainable development" and new theories of green growth and green capitalism (Huan 2016b, 2017). At the same time, Huan is sceptical of romanticised visions of environmental movements, which have become the reference of Western environmental political theorists. Although Huan has been keen to present his research in ways that fit with the political discourse, as for instance in his 2018 NSSF annual project entitled "Xi Jinping's Thought on Socialist Eco-Civilisation with Chinese Characteristics in the New Era," (47) Huan clearly distinguishes his theory of socialist eco-civilisation from the political discourse. He acknowledges its "catchall" nature and sees his role as pushing the CCP leadership to be "genuinely socialist."

However, even for Huan, it seems challenging to bridge theory and practice when it comes to discussing China's situation, and hence to present EC as a theory of social-ecological transformation grounded in China's experience of modernisation. The theoretical impossibility of theorising the capitalist and accumulative practices in a "socialist country" such as China means that the only way to criticise the policies embraced by China's key environmental and climate policy-makers in a way that is audible in the domestic sphere is to address them towards the "Western" capitalist model, while pleading for China to propose a different model instead of "competing for hegemony" (zhengdou baquan 争斗霸权) (Huan 2016b).

Wang Zhihe, as director of the Institute for Postmodern Development of China, has promoted more radical ontologies of man-nature relations. Building on the notion of "constructive post-modernism" proposed by Western philosophers David Griffin and John Cobb, he articulates an alternative to the century-long dream of modernisation endorsed by Chinese leaders. This approach especially calls into question the anthropocentrism of modernisation and supports the development of post-modern, eco-centred values "from an organic, relational, non-dualistic perspective that is far more congenial to classical Asian thinking in general, and Chinese in particular" (Wang et al. 2014). (48) However, although this approach has merits, it must be very carefully crafted if it is to avoid distorted reification of Chinese cultural heritage, which is too easily co-opted by nationalist agendas (Heurtebise 2017; Goldin 2005). Moreover, as Wang himself recognises, the "postmodern turn" has not culturally taken root in China yet, and ascetic lifestyles such as that adopted by Liao Xiaoyi, leader of the NGO Global Village of Beijing (Beijing diqiu cun 北京地球村), and presented as a role model of "Chinese-style environmental protection," are no less marginal in China than in the West (Cao and Yin 2014). Moreover, this "deep green", mainly cultural, advocacy does not address the failure of institutions and vested interests as well as Huan's eco-socialist theory.

Despite their divergences, both scholars share a critical distance towards state ideology, a sustained interest in engaging with like-minded foreign scholars, and a rejection of "parochial nationalism" (Wang 2012) grounded in the understanding that "China has become an integral part of the multiple crises of the contemporary world" (Huan 2016a). Huan has expressly rejected the culturalist interpretations of EC. While he supports the re-interpretation of China's ancient philosophies, like Wang Zhihe he is fully aware of the reconstruction at play, and he insists that all civilisations, not only China's, have ecological values and traditions to pull from (Huan 2016a). He therefore worries that the politicisation of ecological civilisation may render "critical academic study and international dialogue very difficult, if not impossible" (Huan 2016a). Hence, Huan has collaborated extensively with the German professor
Ulrich Brand, supported by the Rosa Luxemburg Foundation in Germany, in the promotion of a global network of "alternative development models." Similarly, Wang Zhihe has organised 12 international forums on ecological civilisation with a consortium of Chinese and American universities since 2006. ${ }^{(49)}$

\section{Conclusion: Towards a Chinese social science contribution to global sustainability}

Aurore Merle has argued that, in the reform era, China's social science research has become progressively de-ideologised, and that the development by Chinese scholars of a critically reflexive attitude towards Western theories, paired with the active search for alternative approaches, was a welcome evolution (Merle 2004). Others, such as Wang Hui, have on the contrary denounced what they considered the abdication of Chinese intellectuals following the Tiananmen crackdown and their uncritical acquiescence to the modernisation narrative served by the Party, covered up in "professionalism" and a-political "scientism" (Wang and Karl 1998).

Ecological civilisation demonstrates the continued tension between propaganda and science and the difficulty of circumventing the implied political claim that Chinese scientific concepts and theory must be necessarily supportive of, if not identical to, CCP propaganda. If such a project, which appears in official policy documents, were pursued to its full extent, it would imply a significant re-ideologization of China's social science research. However, this article has also shown that the fuzzy and evolving value content of EC as a political discourse has left room for the development of a range of meanings and theories of sustainability, including some that have fruitfully engaged with global research. Nonetheless, it remains true that articulating an original theoretical position on sustainability that takes on board the criticism of economic globalisation formulated by environmental thinkers since the 1970 s and its implications for China remains a real intellectual challenge. First, all references to EC converge on an idealistic narrative of the future, or "future perfect tense," as Marinelli (2018) has called it, which supports the CCP's claim to power based on its promise to bring about progress and the betterment of Chinese society, as well as the world. Secondly, abandoning "development" for "civilisation" has emphasised a shift from the economic to the political, the cultural, and the moral, which are domains over which the CCP has considerably reinforced its doctrinal grip. Environmental discourses that challenge this positive vision of the future are excluded, as well as those implying that a precondition for achieving the ecological transition is a more radical change in the country's political structure. In this context, the transformative reach of EC as a theory of sustainability is thus politically constrained.

For a fruitful intellectual dialogue on sustainability involving China to take place, it is essential to distinguish between those who try to develop an EC theory based on political philosophy principles and a general interrogation of the means and ends of economic and political modernity based on the Chinese experience, from those who hold that EC designates the model of

47. List of 2018 NSSF research projects published on 5 June 2018, http://www.npopsscn.gov.cn/n1/2018/0605/c219469-30037269.htm (accessed on 23 June 2018).

48. See the introduction to constructive postmodernism by Pr. John Cobb. "Constructive Postmodernism," Religion Online, https://www.religion-online.org/article/constructive-postmodernism/ (accessed on 15 October 2018).

49. An introduction is presented on the webpage of the Institute for Postmodern Development in China: http://postmodernchina.org/ (accessed on 15 October 2018). 
environmental governance carried out by the Chinese government today. This cannot be achieved when theory and practice are confused and when the global rise of China is simplistically equated with the replacement of an "ecocidal" Western hegemony by a presumably more "ecologically civilised" Chinese hegemony (e.g. Gare 2017).

The same reasoning arguably holds for Chinese social sciences more generally. Chinese researchers and thinkers undeniably have a lot of knowledge to contribute, not only to our understanding of China but also to our understanding of global problems such as environmental change and ecological transformations. However, this can be fruitful only in an in- formed and nuanced dialogue that serves knowledge enhancement, rather than power.

\section{Coraline Goron is a Wiener-Anspach postdoctoral researcher affiliated with the Oxford University China Centre, and Oxford St. Antony's College. \\ University of Oxford China Centre, Dickson Poon Building, Canterbury Road, Oxford OX2 6LU (Coraline.goron@sant.ox.ac.uk).}

Manuscript received on 26 June 2018. Accepted on 8 October 2018.

\section{References}

BAO, Mahong. 2004. "Environmental History in China." Environment and History 10(4): 475-99.

BARME, Gérémie R. 2013. "Engineering Chinese Civilization." In Australian Centre on China in the World, Civilising China. The China Story Yearbook 2013. Canberra: The Australian National University.

BRIDGE, Gavin, James MCCARTHY, and Tom PERREAULT. 2015. "Editors' Introduction." In Gavin et al. (eds.), The Routledge Handbook of Political Economy. New-York: Routledge. 1-3.

CAO, Baoyin, and Wujin YIN. 2014. Ecological Civilization of Contemporary China. Beijing: China International Press.

CARTER, Neil, and Arthur P. J. MOL. 2007. Environmental Governance in China. Oxon: Routledge.

CCICED. 2016. "China's Ecological Civilization and the World." 2016 Issues Paper December 2016. http://www.cciced.net/cciceden/POLICY/rr/Issuespaper/201612/P020161214521507778827.pdf (accessed on 15 October 2018).

CHAO Bai 潮白. 2013. "'倒逼'意味着 被动'” ('Daobi' yiweizhi 'beidong', Daobi means being compelled). Nanfang ribao 1 February 2013.

CHEN, Jia-Ching. 2012. "Greening Dispossession. Environmental Governance and Socio-Spatial Transformation in Yixing, China." In Tony Roshan Samara, Shenjing He, and Guo Chen (eds.), Locating Right to the City in the Global South. Oxon: Routledge. 81-104.

CHEN, Jining. 2017. "National Working Conference on Environmental Protection Held in Beijing." National Working Conference on Environmental Protection Held in Beijing. http://english.sepa.gov.cn/News_service/ Photo/201701/t20170123_395162.shtml (accessed on 15 October 2018).

DONG Xiaolin 董小林. 2010. 当代中国环境社会学建构 (Dangda Zhongguo huanjing shehuixue jiangou, Contemporary Chinese environmental sociology construction). Beijing: Shehui kexue wenxian chubanshe.

ECONOMY, Elizabeth. 1997. "Chinese Policy-Making and Global Climate Change: Two-Front Diplomacy and the International Community." In Miranda A. Schreurs and Elizabeth Economy (eds.), The Internationalization of Environmental Protection. Cambridge, England; New York: Cambridge University Press. 19-42.

FEl Xiaotong 费孝通. 1984. “及早重视小城镇的环境污染问题” (Jizao zhongshi xiaochengzhen de huanjing wuran wenti, Pay early attention to environmental pollution in small towns). Shuitu baochi tongbao 2: 31-3.

China Dialogue. 2018. "Economies have to decarbonize to stay competitive, says former UNFCCC chief." https://www.chinadialogue.net/blog/ 10654-Economies-have-to-decarbonise-to-stay-competitive-says-former-UNFCCC-chief/en (accessed on 15 October 2018).

FOSTER, John Bellamy. 2017. "The Earth-System Crisis and Ecological Civilization: A Marxian View." International Critical Thought 7(4): 439-58.
FRENKIEL, Émilie. 2011. "Note préliminaire sur la condition des universitaires en Chine" (Preliminary note on the status of academics in China). Critique Internationale 2011/1(50): 129-44.

GAFFRIC, Gwennaël, and Jean-Yves HEURTEBISE. 2013. "L'écologie, Confucius et la Démocratie. Critique de la Rhétorique Chinoise de 'Civilisation Écologique'" (Ecology, Confucius and democracy. Criticism of the Chinese rhetoric of 'ecological civilisation'). Écologie \& Politique 2(47): 51-61.

GAO Wenwu 高文武 and GUAN Shengxia 关胜侠. 2012. “建设生态文 明必须同时调整人与人、人与自然的关系” (Jianshe shengtai wenming bixu tongshi tiaozheng ren yu ren, ren yu ziran de guanxi, Constructing an ecological civilisation necessitates at the same time to adjust people to people and people to nature relations). Lilun cankao 2012(5).

GARE, Arran. 2016. The Philosophical Foundations of Ecological Civilization: A Manifesto for the Future. Oxford: Routledge.

GEALL, Sam. 2015. "Interpreting Ecological Civilisation (part one)." China Dialogue 6 July 2015. https://www.chinadialogue.net/article/show/single/en/8018-Interpreting-ecological-civilization-part-one- (accessed on 15 October 2018).

GEALL, Sam, and Ely ADRIAN. 2017. "Narratives and Pathways towards an Ecological Civilization in Contemporary China." The University of Sussex. http://sro.sussex.ac.uk/71477/ (accessed on 15 October 2018).

GUO Fang 郭芳. 2015. “潘岳曾掀3次环评风暴叫停千亿元项目 后不 分管环评” (Pan Yue zeng xian 3 ci huanping fengbao jiao ting gian yi yuan xiangmu hou bu fenguan huanping, Pan Yue no longer in charge of environmental impact assessment after halting hundreds billion yuan of industrial projects and unleashing 3 IEAs storms). Zhongguo jingji zhoukan August. http://www.chinanews.com/gn/2015/08-18/7473027.shtml (accessed on 15 October 2018).

HEURTEBISE, Jean-Yves. 2017. "Sustainability and Ecological Civilization in the Age of Anthropocene: An Epistemological Analysis of the Psychosocial and 'Culturalist' Interpretations of Global Environmental Risks." Sustainability 9(8): 1331.

HOLBIG, Heike. 2014. "Shifting Ideologics of Research Funding: The CCP's National Planning Office for Philosophy and Social Sciences." Journal of Current Chinese Affairs 43(2): 13-32.

HOLBIG, Heike. 2018. "Whose New Normal? Framing the Economic Slowdown Under Xi Jinping." Journal of Chinese Political Science 23(3): 341-63.

HUAN, Qingzhi. 2007. "Ecological Modernisation: A Realistic Green Road for China?" Environmental Politics 16(4): 683-87.

HUAN Qingzhi 邭庆治. 2014. “生态文明概念的四重意蕴：一种术语 学的禅意" (Shengtai wenming gainian de si zhong yiyun: yi zhong shuyu xue de chanyi, The four connotations of the concept of ecological civilisation: a terminology interpretation). Jianghan luntan 2014/11: 5-10.

HUAN Qingzhi 狍庆治. 2015. “生态文明理论及其绿色变革意蕴” (Shengtai wenming lilun jiqi lüse biange yiyun, The theory of ecological civilisation and the implications of its green transformation). Makesi zhuyi yu xianshi (5): 167-75. 
HUAN, Qingzhi. 2016a. "Socialist Eco-Civilization and Social-Ecological Transformation." Capitalism Nature Socialism 27(2): 51-66.

HUAN Qingzhi 邭庆治. 2016b. “碳政治的生态帝国主义逻辑批判及其 超越” (Tan zhengzhi de shengtai diguozhuyi luoji pipan jiqi chaoyue, A logical critique of the ecological imperialism of "carbon politics" and its transcendence). Zhongguo shehui kexue 2016/3: 24-41.

HUAN, Qingzhi. 2017. "Criticism of the Logic of the Ecological Imperialism of 'Carbon Politics' and Its Transcendence." Social Sciences in China 38(2): 76-94.

HUANG Haotao 黄浩涛. 2015. “生态兴则文明兴 生态衰则文明衰一 一系统学习习近平总书记十八大前后关于生态文明建设的重要论 述” (Shengtai xing ze wenming xing shengtai shuai ze wenming shuaixitong xuexi Xi Jinping zong shuji shiba da qianhou guanyu shengtai wenming jianshe de zhongyao lunshu, The rise of civilisation follows the rise of ecological civilisation-systematically study the important discourse of ecological civilisation by Party General Secretary Xi Jinping pursuant to the 18th Party Congress). Xuexi shibao 3 March 2015 http://www.wxyjs.org.cn/Xxgcxjpzsjxljhjszl/gydltjstwmjs/201604/t20160 426_213285.html (accessed on 15 October 2018).

HUBBERT, Jennifer. 2015. "'We Are Not That Kind of Developing Country': Environmental Awareness in Contemporary China." In Cindy Isenhour, Gary McDonogh, and Melissa Checker (eds.), Sustainability in the Global City. Myth and Practice. Cambridge, New York: Cambridge University Press. 29-54.

JENCO, Leigh. 2013. "Chinese Political Ideologies." In Michael Freeden and Marc Stears (eds.), The Oxford Handbook of Political Ideologies. Oxford Handbooks Online.

KE, Jiahua. 2013. "Introduction." Social Sciences in China 34(4): 139-42.

KEELEY, James, and ZHENG Yisheng. 2011. Green China: Chinese Insights on Environment and Development. London: International Institute for Environment and Development (IIED).

LI Hongwei 李宏伟. 2012. “生态文明建设的科学内涵与当代中国生 态文明建设" (Shengtai wenming jianshe de kexue neihan yu dangda Zhongguo shengtai wenming jianshe, The scientific connotation of the construction of ecological civilisation and the construction of ecological civilisation in contemporary China). Lilun cankao 2012(5): 7-9.

LORA-WAINWRIGHT, Anna. 2017. Resigned Activism. Living with Pollution in Rural China. Cambridge, Massachusetts: The MIT Press.

LORD, Elizabeth. 2018. Building an Ecological Civilization across the Rural/Urban Divide and the Politics of Environmental Knowledge Production in Contemporary China. Toronto: University of Toronto.

LÜ, Zhongmei. 2013. "Roadmap for the Construction of an Ecological Rule of Law in China." Social Sciences in China 34(4): 162-70.

MARINELLI, Maurizio. 2018. "How to Build a 'Beautiful China' in the Anthropocene. The Political Discourse and the Intellectual Debate on Ecological Civilization." Journal of Chinese Political Science Online first. https://doi.org/10.1007/s11366-018-9538-7 (accessed on 15 October 2018).

MERLE, Aurore. 2004. "Towards a Chinese Sociology for 'Communist Civilisation' in Peking, a Group of Sociologists at Tsinghua University Are Proposing a New Course of Research." China Perspectives 2004(52): 4-15. MORRISON, Roy. 1995. Ecological Democracy. Boston: South End Press.

NIU Wenyuan 牛文元. 2010. “生态文明与绿色世界” (Shengtai wenming yu lüse shijie, Ecological civilisation and green world). Shengtai wenming xiehui. http://www.ceca-china.org/news_view.asp?id=1016 (accessed on 15 October 2018).

OSWALD, James P. F. 2014. "What Does Eco-Civilization 生态文明 Mean?" The China Story (blog) 4 September 2014. https://www.thechinastory.org/ 2014/09/what-does-eco-civilization-mean/ (accessed on 15 October 2018).
PAN, Jiahua. 2013. "Ensuring Ecological Security by Adapting to Carrying Capacity." Social Sciences in China 34(4): 154-61.

PAN, Jiahua 2016. China's Environmental Governing and Ecological Civilization. Online: Springer.

PAN Yue and ZHOU Jigang. 2006. "The Rich Consume and the Poor Suffer the Pollution." China Dialogue 27 October 2006. https://www.chinadialogue.net/article/show/single/en/493-The-rich-consume-and-the-poorsuffer-the-pollution- (accessed on 15 October 2018).

PANYue 潘岳. 2006a. “论社会主义生态文明” (Lun shehuizhuyi shengtai wenming, On a socialist ecological civilisation). Lüye October 2006. http://www.zhb.gov.cn/hjyw/200702/t20070206_100622.htm (accessed on 15 October 2018).

PING, Ren. 2012. "Systematic Innovation, Comprehensive Development and Going Global: Some Thoughts on the Construction of an Innovation System for Philosophy and Social Sciences in China during the '12th FiveYear Plan' Period." Social Sciences in China 33(3): 142-56.

ROCCA, Jean-Louis. 2008. "De la sociologie en territoire chinois" (Sociology in Chinese territory). In Jean-Louis Rocca (ed.), La société chinoise vue par ses sociologues (Chinese society from the perspective of its sociologists). Paris: Science Po Press. 21-43.

SHAMBAUGH, David. 2007. "Let a Thousand Democracies Bloom." New York Times 6 July 2007. http://www.nytimes.com/2007/07/06/opinion/ 06iht-edsham.1.6530408.html (accessed on 15 October 2018).

SHEN, Keting. 2011. "Local and Central Government Relations: Impulsive Investments and Sustainable Development." In James Keeley and Yisheng Zheng (eds.), Green China: Chinese Insights on Environment and Development. London: International Institute for Environment and Development (IIED). 172-83.

WAN, Junren. 2013. "The Philosophical Wisdom and Action Implications of 'Beautiful China'." Social Sciences in China 34(4): 143-53.

WANG, Alex. 2013. "Search for Sustainable Legitimacy: Environmental Law and Bureaucracy in China." Harvard Environmental Law Review 37: 366-440.

WANG, Alex 2018. "Symbolic Legitimation in Chinese Reform." Environmental Law (Forthcoming).

WANG Canfa 王灿发. 2014. “论生态文明建设法律保障体系的建构” (Lun shengtai wenming jianshe falü baozhang tixi de jiangou, On the construction of a legal guarantee system for the ecological civilisation construction). Zhongguo faxue 2014(3): 34-53.

WANG, Hui, and Rebecca E. KARL. 1998. "Contemporary Chinese Thought and the Question of Modernity." Social Text 55: 9-44.

WANG, Jing, and Mingyuan WANG. 2011. "Environmental Rule of Law in China:Why the System Isn't Working." In James Keeley and Yisheng Zheng (eds.), Green China: Chinese Insights on Environment and Development. London: International Institute for Environment and Development (IIED). 160-72.

WANG Jin 汪劲. 2010. “环境法治30年为何难治污染? ” (Huanjing fazhi 30 nian weihe nan zhi wuran, Environmental rule of law for 30 year, why is pollution intractable?). Tengxun lüse August. http://news.99.com/a/ 20100818/001246.htm (accessed on 15 October 2018).

WANG, Xiaoyi. 2013. "Building a Fair and Conservation-Oriented Society." Social Sciences in China 34(4): 171-79.

WANG, Zhihe. 2012. "Ecological Marxism in China." Monthly Review63(9): 36-44.

WANG, Zhihe, Huili HE, and Meijun FAN. 2014. "The Ecological Civilization Debate in China: The Role of Ecological Marxism and Constructive Postmodernism - Beyond the Predicament of Legislation." Monthly Review 66(6): 37-59.

WU, Fengshi. 2009. "Environmental Politics in China: An Issue Area in Review." Journal of Chinese Political Science 14(4): 383-406. 
XI Jinping. 2014. Xi Jinping: The governance of China. Beijing: Foreign Languages Press.

YEH, Emily T. 2013. "The Politics of Conservation in Contemporary Rural China." The Journal of Peasant Studies 40(6): 1165-88.

YEH, Emily T. 2015. "Political Ecology in and of China." In Raymond L. Bryant (ed.), The International Handbook of Political Ecology. Cheltenham, Northampton, MA: Edward Elgar Publishing. 619-33.

YU, Hai, Yongliang YANG, Felix RICHETER, and Laurence BRAHM. 2014. "Institutional Innovation of Ecological Civilization: Conceptual Understanding and Experience Reference." EU-China Policy Dialogue Support Facility (PDSF) II and Policy Reseach Center for Environment and Economy (PRCEE). Beijing: European Union and China's Ministry of Environmental Protection. http://www.prcee.org/piw/wwwroot/Demo/upload/Attach/ mrbj/2530394430.pdf (accessed on 15 October 2018).

YU Keping 俞可平. 2005. “科学发展观与生态文明” (Kexue fazhan guan yu shengtai wenming, Scientific development and ecological civilisation). Makesizhuyi yu xianshi 2005(4): 4-5.

YU Chun 徐春. 2010. “对生态文明概念的理论阐释” (Dui shengtai wenming gainian de lilun chanshi, Theoretical explanation of the concept of ecological civilisation). Beijing daxue xue bao 2010(1): 61-3.

ZHANG Weiwei 张维为. 2008. “生态文明: 中国的机遇” (Shengtai wenming: Zhongguo de jiyu, Ecological civilisation: China's opportunity). Xuexi shibao March 2008. http://www.china.com.cn/xxsb/txt/2008-03/10/content_12170989.htm (accessed on 15 October 2018).

ZHANG Xunhua and WANG Yan. 2013. "Essentials of the Construction of an Ecological Civilization." Social Sciences in China 34(4): 180-92.

ZHANG, Joy, and Michael BARR. 2013. Green Politics in China: Environmental Governance and State-Society Relations. London: Pluto Press.
ZHANG, Leitan. 2008. "La crise de la recherche fondamentale. Recherche académique, logique du marché et intervention étatique" (The crisis of fundamental research. academic research, market logic and state intervention). In Jean-Louis Rocca (ed.), La société chinoise vue par ses sociologues (Chinese society from the perspective of its sociologists). Paris: Science Po Press. 289-307.

ZHAO Jiuzhou 赵九洲. 2011. "中国环境史研究的认识误区与应对方 法" (Zhongguo huanjing shi yanjiu de renshi wuqu yu yingdui fangfa, Misunderstandings in Chinese environmental history and coping methods). Xueshu yanjiu 2011(8): 122-7.

ZHENG, Yisheng, and LIANG, Fan (eds). 2016. Chinese Research Perspectives on the Environment. Special Volume: Critical Essays on China's Environment and Development. Amsterdam: Brill.

ZHENG, Hangsheng. 2011. "Academic Discourse Right/Power and the Development of Chinese Sociology." Social Sciences in China 32(4): 92-105.

ZHOU Shengxian周生贤. 2009. “以生态文明建设为指导构建能源与 环境的和谐" (Yi shengtai wenming jianshe wei zhidao goujian nengyuan yu huanjing de hexie, Harmonising the relationship between energy and environment under the guidance of eco-civilisation). Annual Conference of China Council for International Cooperation on Environment and Development. http://english.sepa.gov.cn/Events/Special_Topics/AGM_1/ 2009agmpp/speech09/201605/t20160524_344776.shtml (accessed on 15 October 2018).

ZOU, Yilin. 2013. "The Man-Nature Relationship in Chinese History: A Study from Multiple Perspectives." Social Sciences in China 34(4): 193201. 